\title{
Preparation of Cetane Improver for Diesel Fuel and Study It's Performance
}

\author{
Muna Mahmood Khudhair, Sajeda Abbas Husain, Shafaa Mahdi Salih and Zahraa Mahmed Jassim \\ Ministry of Science and Technology, Directorate of Materials Research, Petroleum and \\ Petrochemical Research Centre, Baghdad-Iraq \\ E-mail: munamahmood68@yahoo.com
}

\begin{abstract}
Cetane improver is an additive that improves the cetane number of diesel fuel. Now the world focus on using cetane improvers which are friend to environmental that biodegradable and reduce exhaust of gases such as carbon monoxide and oxide of nitrogen.

Cetane improver was prepared by reacting methyl ethyl ester of long chain fatty acids with nitric acid in the presence of acetic anhydride in nitration process, while the ester can be produced from castor oil through transesterification.

In this work the optimum conditions of nitration reaction which includes mole ratio of nitric acid, temperature and time of reaction were studied according to the results of percent of yield and absorbance peak area of $\mathrm{OH}$ group of starting materials.

It was found that 10 is best mole ratio of nitric acid to esters, $10-20^{\circ} \mathrm{c}$ temperature for 3 hours time.

The nitrated products were analyzed as cetane number enhancers adding it to diesel fuel at 0.1 and $0.05 \%$ concentration and it was found that the cetane number of diesel fuel was increased at $25 \%$ percentage. [DOI: $10.22401 /$ JNUS.20.1.06]
\end{abstract}

Keywords: Cetane Improver, Diesel Fuel, Nitrated Compounds, Vegetable Ester.

\section{Introduction}

Engine fuels are comprised of green high quality blending components and highly efficient. Nowadays, application of high performance additives is essential to meet the required fuel properties and protect the engine and the environment [1].

The implementation of stringent diesel engine emissions regulations is growing worldwide. The emission reduction of a combined NOx and $\mathrm{HC}$ will require a combination of new engine technology and economically viable low emission diesel fuels [2]. It is widely accepted that increasing the cetane number represents one option for production of cleaner burning diesel fuels. Numerous studies have demonstrated that increasing the cetane number of the fuel significantly reduces all the regulated emissions [3].

Increasing the cetane number of diesel fuel can be achieved by lowering aromatic content of the fuel through hydrotreating and or by addition of chemical cetane improvers. It is generally recognized that chemical cetane improvement additives represent a low cost alternative to obtaining higher cetane number achieved through aromatic reduction. Cetane improvers are those compounds that readily decompose to form free radicals, which in-turn promote the rate of initiation. This increased rate of chain initiation leads to improved ignition characteristics of diesel fuel. Chemicals selected from alkyl nitrates, certain peroxides, tetraazoles, and thioaldehydes can serve as cetane improvers. Due to their low costs, alkyl nitrates have played the most significant role in commercial use. 2Ethylhexyl nitrate (EHN) has been used for a number of years and today is the predominant cetane improving additive in the marketplace [3].

Fatty acid alkyl esters and or their derivatives are able to substitute diesel fuels and or their additives. The use of esters can reduce the import dependence of crude oil and its products. The application of esters based on vegetable oils in premium quality diesel fuels ensures environmental advantages (lower $\mathrm{CO}_{2}$ emission, biodegradability, non-toxic. Significant utilization option of vegetable oils resulting in substantial value addition is the 
production of additives that are useful for various industrial purposes. This utilization option is not only motivated by their renewable nature and their superior biodegradability compared to synthetic products, but also by their applicability in various chemical reactions or structural modifications due to the unique distribution of their unsaturated bonds and their reactive functional groups [4-5].

The recent research aims to syntheses nitro derivative of methyl ethyl ester of long chain fatty acids, study the optimum condition of nitration reaction and use the product to improve the cetane index of diesel fuel.

\section{Materials and Methods Materials}

Anhydrous Methanol of $99.95 \%$ purity, Anhydrous Ethanol of $99.95 \%$, hexane, potassium hydroxide, and sodium hydroxide of analytical reagent grade were obtained from Sigma company.Castor oil was obtained from Mom company in India. Diesel fuel was obtained from Al-dora refinery in Iraq which has specifications shown in table.

Table (1)

Specifications of diesel fuel.

\begin{tabular}{||c||c|}
\hline \multicolumn{1}{|c||}{ Test } & Result \\
\hline \hline Specific gravity at $15.6^{\circ} \mathrm{C}$ & 0.8285 \\
\hline Flash point ${ }^{\circ} \mathrm{C}$ & 82.3 \\
\hline Pour point ${ }^{\circ} \mathrm{C}$ & -18 \\
\hline Viscosity Cst at $40{ }^{\circ} \mathrm{C}$ & 2.8 \\
\hline \hline Carbon residue wt $\%$ & 0.05 \\
\hline \hline Sulfur w\% & 0.99 \\
\hline Distillation :Initial boiling point & \\
$10 \%$ & 185 \\
$20 \%$ & 218 \\
$30 \%$ & 235 \\
$40 \%$ & 245 \\
$50 \%$ & 254 \\
$60 \%$ & 263 \\
$70 \%$ & 271 \\
$80 \%$ & 280 \\
$90 \%$ & 290 \\
E.P.C. & 300 \\
T.D.\% & 335 \\
Rec. & 99.0 \\
Loss & 0.50 .5 \\
\hline
\end{tabular}

\section{Apparatus and Instruments FTIR Spectrophotometer}

FTIR spectrometry was investigate the compounds formed by transesterification and nitration reactions of castor oil. The spectrum were recorded using shimadzu model 84005 .

\section{Cetane analyzer}

Petroleum quality analyzer octane meter Shatox SX-200 was used to determine the cetane number of fuel samples.

\section{Experimental Procedures \\ Transesterification process}

Castor oil $250 \mathrm{ml}$ was reacted with a solution of $(1 \%)$ potassium hydroxide dissolved in an appropriate quantity of methanol and ethanol at room temperatures. Stirring was continued for 3 hours (for assisting the reaction of oil into methyl ethyl esters) and the product was placed in a separating funnel and left overnight to settle. Glycerol settled to the bottom of the funnel and it was removed. The top layer was taken for purification process [6]. The ester layer may contain unreacted catalyst, methanol, ethanol and residual glycerol. These impurities were removed by water washing method the washing was continued (4-6 times) until the water layer becomes clear [1]. The ester layer was evaporated by using rotary evaporator to remove the water and methanol content present in the product (biodiesel). Finally the ester was dried by calcium chloride and saved [6].

\section{Nitration process}

Conc. nitric acid $60 \mathrm{ml}$ was added to acetic anhydride $180 \mathrm{ml}$ at $0-10^{\circ} \mathrm{C}$ temperature for 1hour with continuous stirring. Methyl ethyl esters of castor oil $100 \mathrm{~g}$ was nitrated with previous prepared mixture of nitric acid and acetic anhydride. Nitration reaction was carried out with variation of number of moles of mixture $(6.6,10,13.3,16.6$ moles $)$ and temperature $\quad\left(0-10^{\circ} \mathrm{c}(\mathrm{T} 1), \quad 10-20^{\circ} \mathrm{c}(\mathrm{T} 2), 20\right.$ $\left.30^{\circ} \mathrm{c}(\mathrm{T} 3)\right)$ as well as reaction time $(0.5,1,3,5,6$ hours). The reaction was quenched with ice water, washed several times with water and sodium bicarbonate solution then dried with drying agent such as calcium chloride. The 
product was analyzed by FTIR spectroscopy [7].

\section{FTIR Analysis}

One drop of the oil was placed on the measurement window, measured and later removed simply with tissue and cleaning of remaining parts with a drop of solvent.

\section{Cetane analyzer}

Using laboratory glassware of volume 75$100 \mathrm{ml}$, fillup the octane meter detector with fuel sample up to full admission, switch on octane meter, and write down readings of cetane readings.

\section{Results and Discussion}

\section{Syntheses of cetane improver}

The nitrated methyl ethyl ester of castor oil was synthesized by transesterification and nitration reactions.

Castor oil may be polymerize in the mineral acids. So, transesterified of the oil is important approach to reduce the viscosity of the origin oil and reduce the cost that is occurred from used solvent in the syntheses of the nitrated product.

Methanol and ethanol are the main alcoholic compound that are used in the syntheses the esters of castor oil in the presence of potassium hydroxide which is react with alcohols to form strong base (equation 1) (alkoxide) to react with castor oil [7].
$\mathrm{KOH}+\mathrm{ROH} \leftrightarrow \mathrm{RO}^{-}+\mathrm{H}_{2} \mathrm{O}$

In the nitration reaction, strong nitrating mixture has been prepared from reacting concentrated nitric acid and acetic anhydride to form nitronium ion (equation 2)

$\mathrm{HNO}_{3}+\left(\mathrm{CH}_{3} \mathrm{CO}\right)_{2} \mathrm{O} \leftrightarrow \mathrm{NO}_{2}^{+}+2 \mathrm{CH}_{3} \mathrm{COO}^{-}+\mathrm{H}_{2} \mathrm{O}$

To syntheses cetane improver, castor oil was selected because it has high percentage of recinoleic acid which has hydroxyl group. The overall reaction may be summarized in scheme (1).

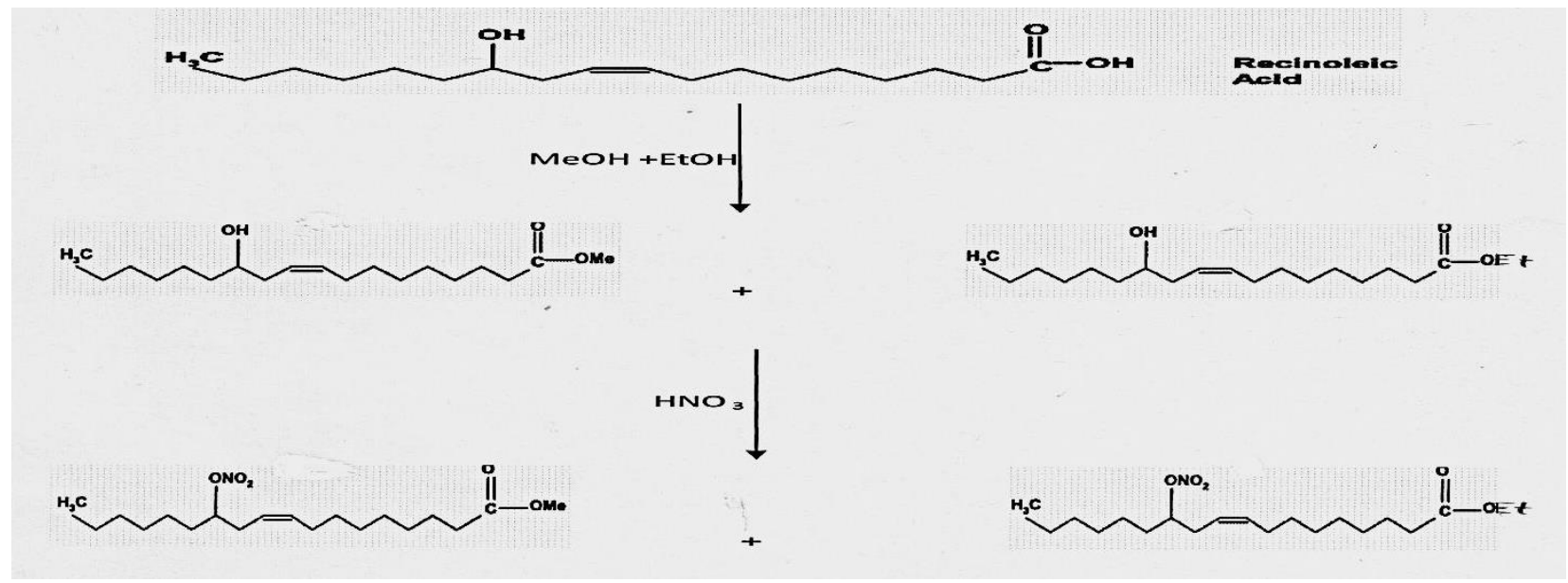

Scheme (1): Synthesis of nitrated methyl ethyl ester of castor oil. 


\section{FTIR Analysis}

FTIR spectroscopy was employed to analyze the esters and nitrated derivatives of castor oil.

Fig.(1). A,B,C showed the spectra of castor oil, esters products, and nitrated products. The spectra of castor oil Fig.(1A) showed absorbance peaks at 3450, 3008, 2922-2852, $1743,1454,1164,968,725 \mathrm{~cm}^{-1}$ related to $\mathrm{OH}, \mathrm{CH}, \mathrm{CH}_{2}, \mathrm{CO}, \mathrm{OCH}_{2}, \mathrm{CO}, \mathrm{CH}_{2}, \mathrm{RCOCR}$, and $\mathrm{CH}_{2}$ groups respectively[8].

Methyl and ethyl esters of castor oil Fig.(1B) showed bands at $1741 \mathrm{~cm}^{-1}$ related to carbonyl group of ester,split the peak of 1454 $\mathrm{cm}^{-1}$ to $1463 \mathrm{~cm}^{-1}$ and $1436 \mathrm{~cm}^{-1}$ bands related to $\mathrm{CH}_{3}$ group,appearance of two bands at $1168 \mathrm{~cm}^{-1}$ and $1195 \mathrm{~cm}^{-1}$, and disappearance of
$968 \mathrm{~cm}^{-1}$ band which means that the triglyceride group was cleavage[8].

FTIR analysis of nitrated methyl and ethyl esters of castor oil Fig.(1C) showed disappearance of $\mathrm{OH}$ group peaks and formation of intense peaks at $1629 \mathrm{~cm}^{-1}$, $1274 \mathrm{~cm}^{-1}$, and $862 \mathrm{~cm}^{-1}$ that represents absorbance of $\mathrm{NO}_{2}$ and $\mathrm{NO}_{3}$ groups [7].

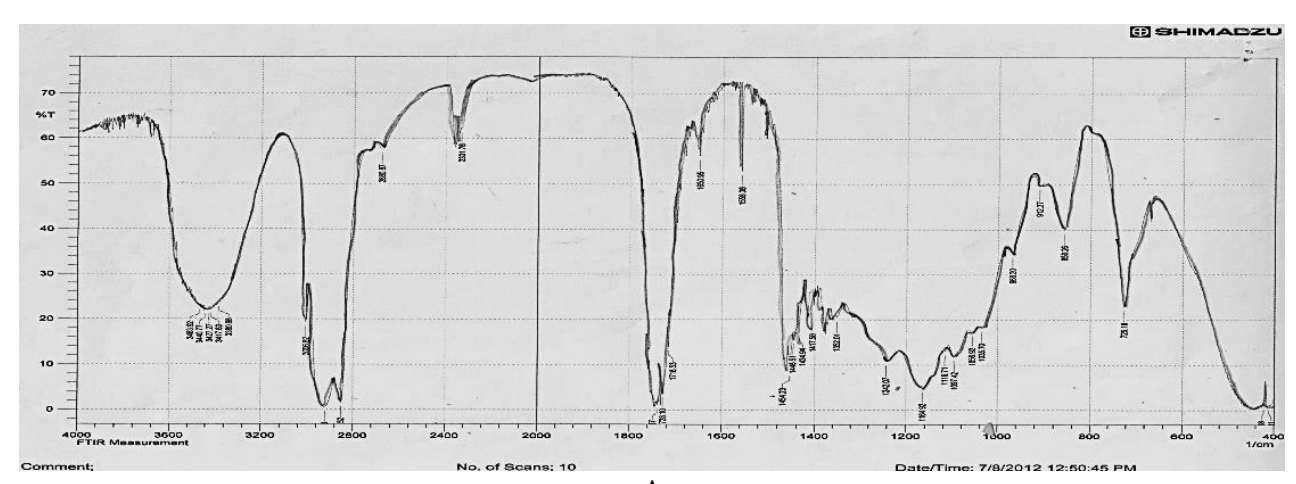

A

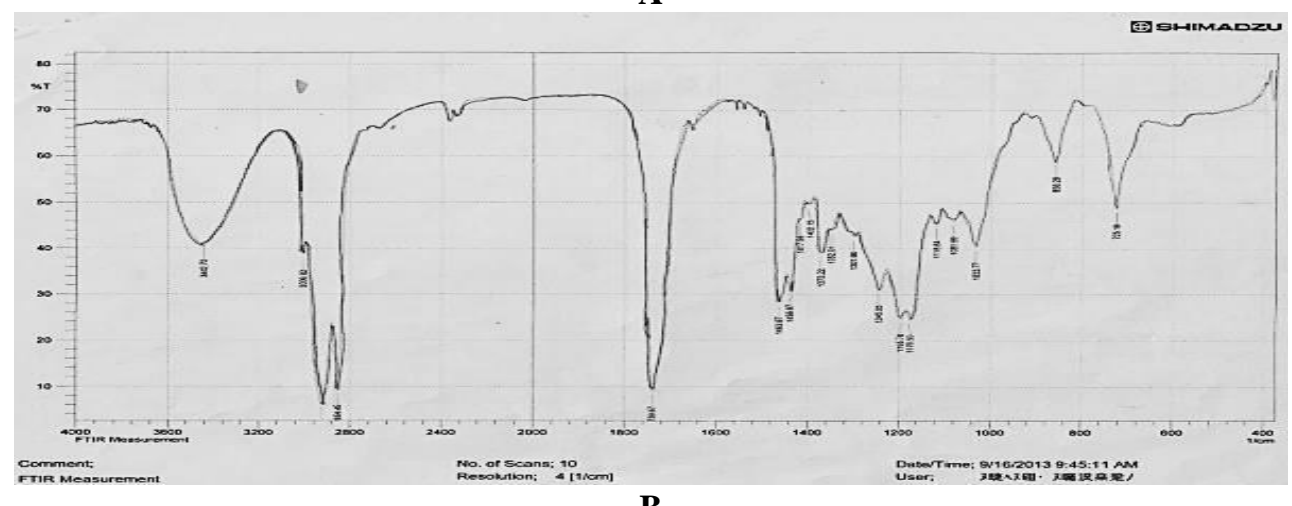

B

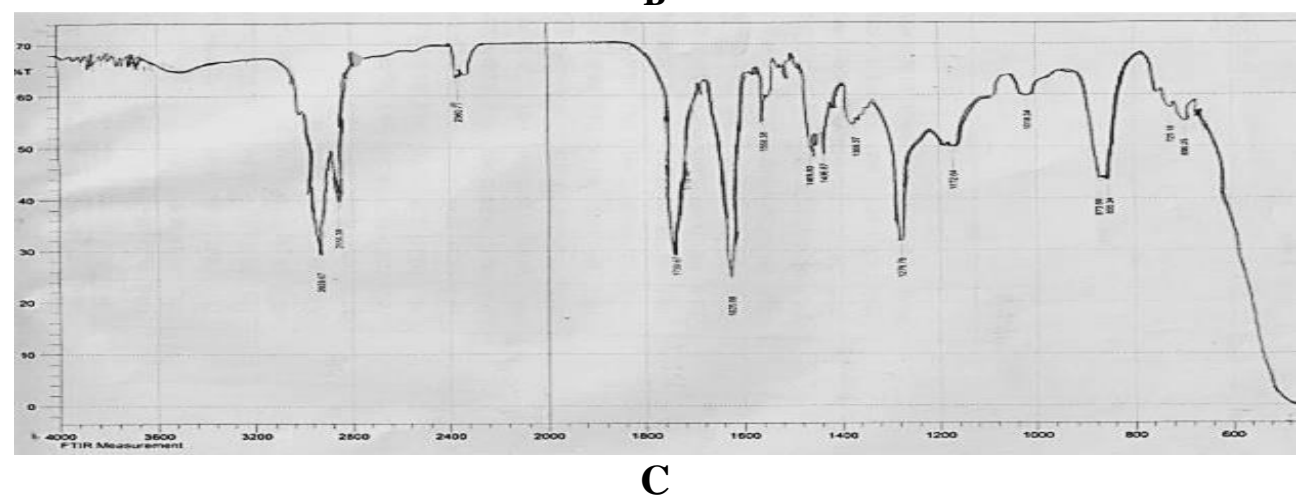

Fig.(1): FTIR spectra of A, castor oil: B, methyl and ethyl esters of castor oil: $C$, nitrated products of esters of castor oil. 
Study the physical properties of methyl ethyl ester of castor oil

Table (2) shows the studied physical properties which include viscosity, specific gravity, and boiling point of methyl ethyl ester of castor oil as comparison them with those of castor oil.

Table (2)

Physical properties of castor oil and its methyl ethyl ester.

\begin{tabular}{||c|c||c|}
\hline Physical properties & castor oil & methyl ethyl ester of castor oil \\
\hline \hline Viscosity Cst at $40^{\circ} \mathrm{C}$ & 210 & 10 \\
\hline \hline Specific gravity at $15.6^{\circ} \mathrm{C}$ & 0.958 & 0.907 \\
\hline Boiling point ${ }^{\circ} \mathrm{C}$ & $>250$ & $>250$ \\
\hline
\end{tabular}

Study the optimum conditions of the reaction of ester of castor oil with nitric acid 1-Effect of mole ratio of nitric acid to ester of castor oil

The experiment was done at different mole ratio of nitric acid to esters of castor oil ranging from 6.6 to 16.6 .

Fig.(2). and (3). Shows that the relationship between mole ratio of nitric acid to esters of castor oil and the yield percentage and absorbance peak area of $\mathrm{OH}$ group respectively.

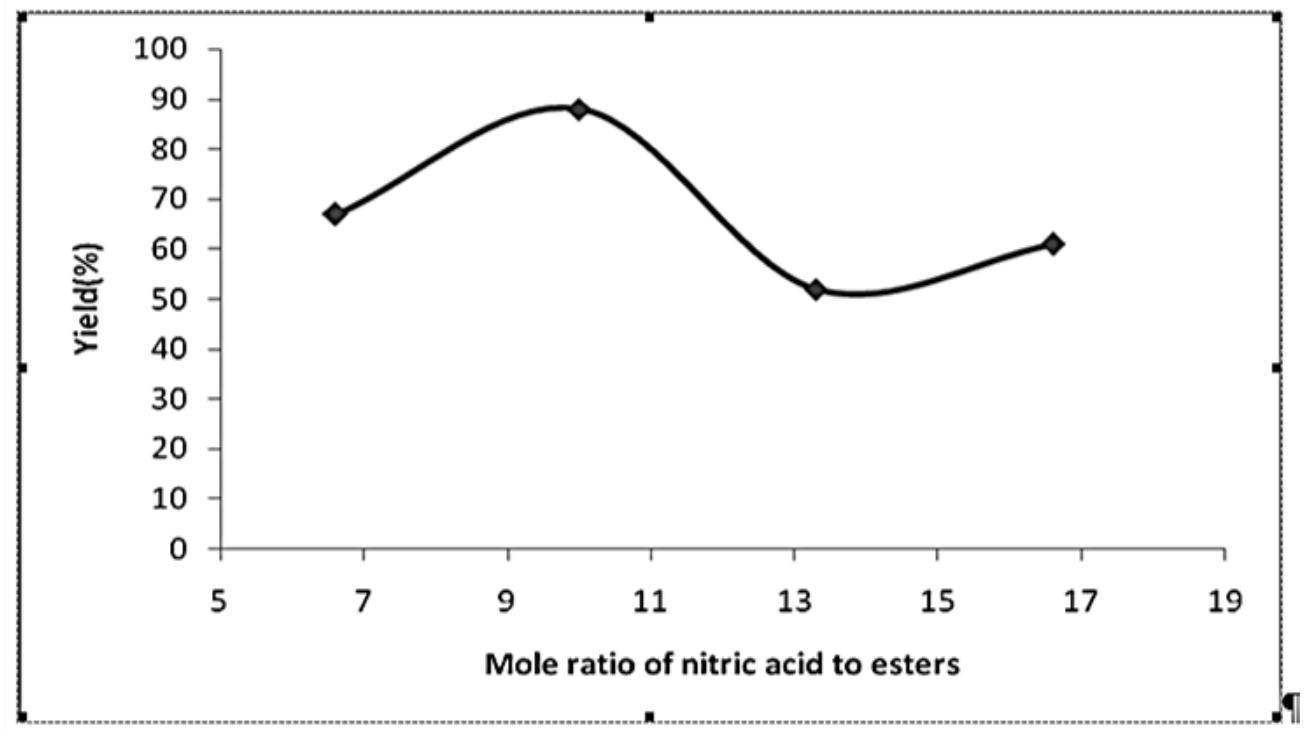

Fig.(2): The relationship between moles of nitric acid and yield percentage. 


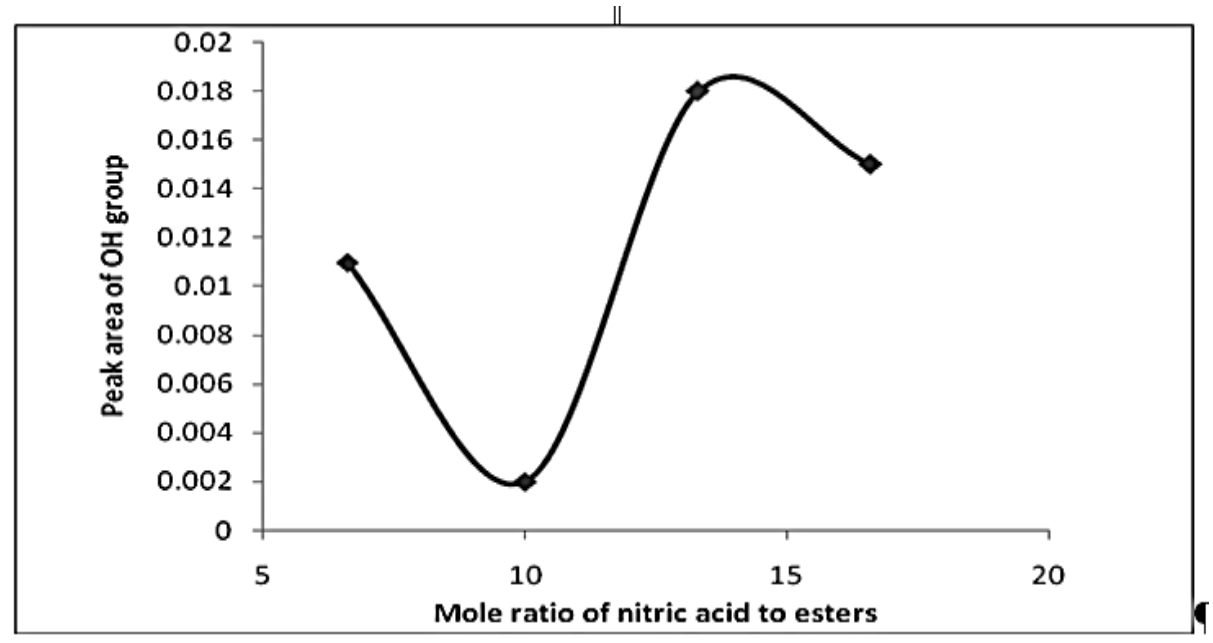

Fig.(3): The relationship between number of moles of nitric acid and absorbance peak area of OH group of product.

Fig.(2) shows that the best yield obtained by using 10 moles and above this the yield was decreased, this may be refer to the formation of products that contained $\mathrm{NO}_{2}$ and $\mathrm{NO}_{3}$ groups that have high polarity, so it is easy to soluble in aqueous solution in separation process [7].

The lower absorbance peak area of $\mathrm{OH}$ group was obtained by using 10 mole ratio of nitric acid to esters of castor oil as shown in Fig.(3).

2-Effect of temperature on preparation of nitrated products of esters of castor oil

Nitration of esters of castor oil was conducted on variation in temperature range $\left(0-10^{\circ} \mathrm{c}(\mathrm{T} 1), \quad 10-20^{\circ} \mathrm{c}(\mathrm{T} 2), \quad 20-30^{\circ} \mathrm{c}(\mathrm{T} 3)\right)$ by using ice bath.

Fig.(4). and (5). shows that increasing in temperature caused increasing in yield and decreasing in absorbance peak area of $\mathrm{OH}$ group of nitrated products from $\mathrm{T} 1$ to $\mathrm{T} 2$,so the best temperature of nitration is $10-20{ }^{\circ} \mathrm{c}$, while from some publications illustrated that the best temperature was $0-10^{\circ} \mathrm{c}$ and this is because the nitration reaction by using acetic anhydride is easy to occur at ambient temperature and do not need for using chillers [7].

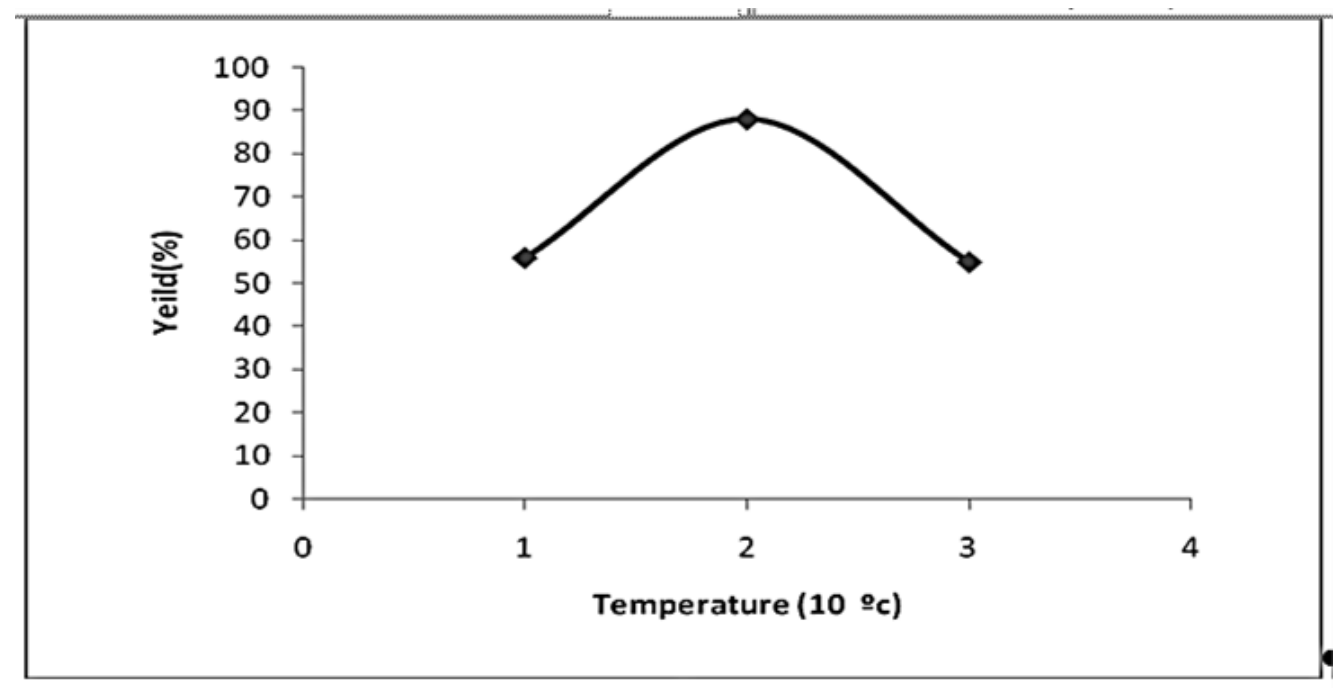

Fig.(4): The relationship between nitration temperature and yield percentage. 


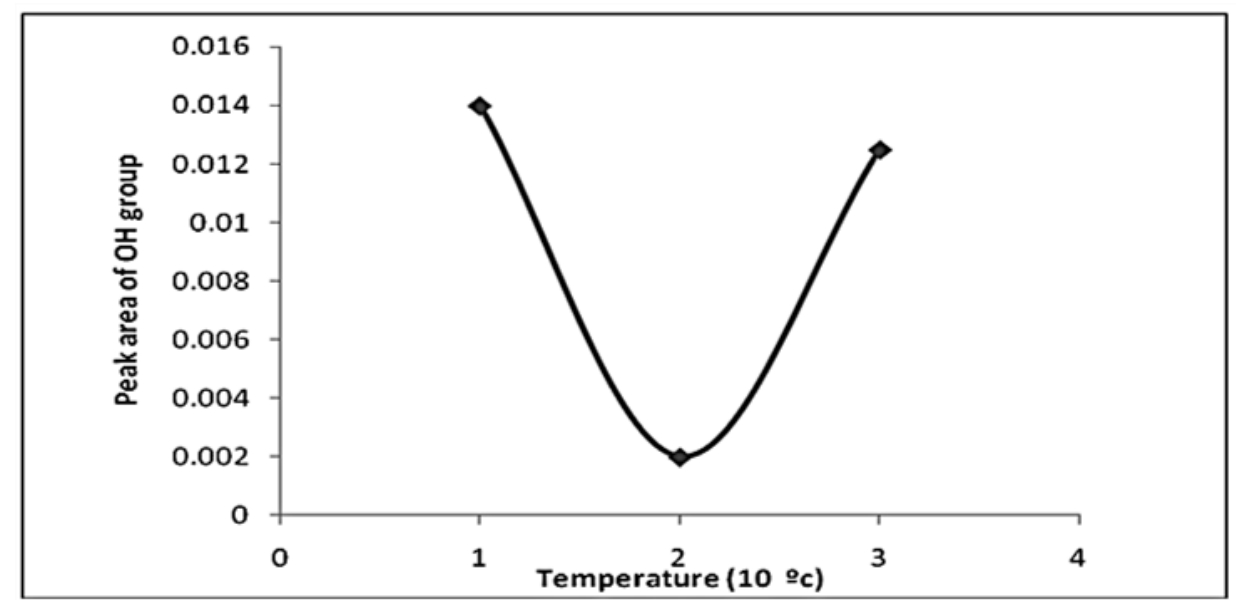

Fig.(5): The relationship between nitration temperature and absorbance peak area of $\mathrm{OH}$ group

NOTE: in figure 4 and 5

\section{of product.}

1 represents $0-10{ }^{\circ} \mathrm{c}(\mathrm{T} 1)$,

2 represents $10-20^{\circ} \mathrm{c}(\mathrm{T} 2)$

3 represents $20-30^{\circ} \mathrm{c}(\mathrm{T} 3)$.

3- Effect of reaction time on preparation of nitrated products of esters of castor oil

Nitration reaction of esters of castor oil was effected by reaction time, so it was applied different time $(0.5,1,3,5,6$ hour $)$ in order to find the optimum time of the reaction by using yield and peak area of $\mathrm{OH}$ group absorbance in nitrated products as indication.

Fig.(6) and (7) shows that the relationship between the reaction time (esters of castor oil and nitrating mixture) and the yield percentage and absorbance peak area of $\mathrm{OH}$ group respectively.

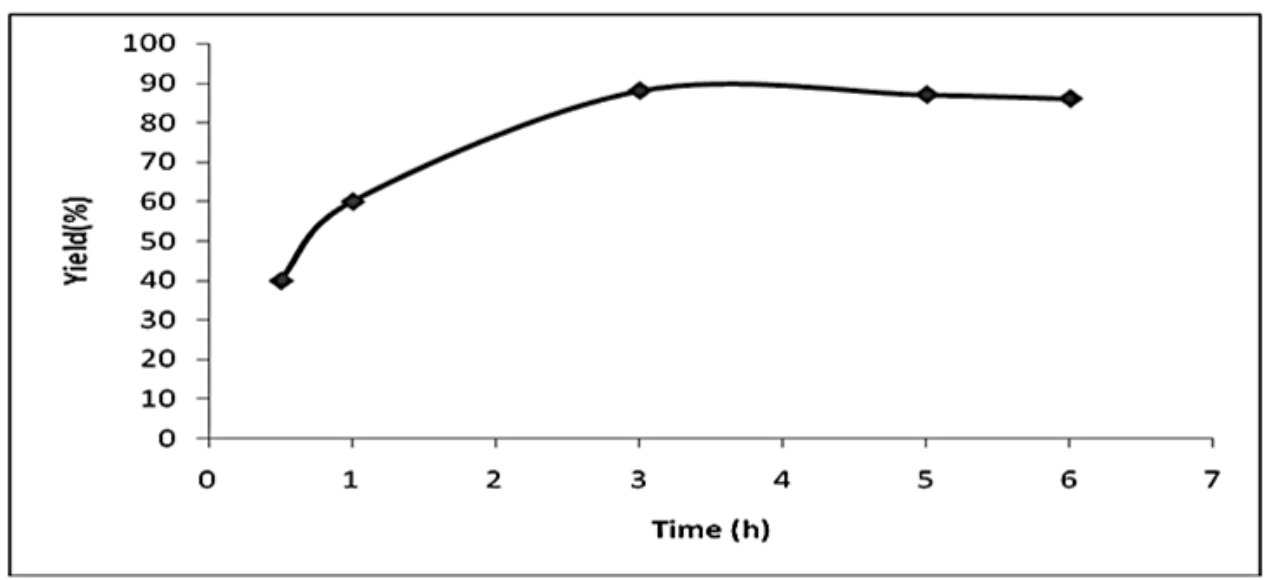

Fig.(6): The relationship between nitration time and yield percentage. 


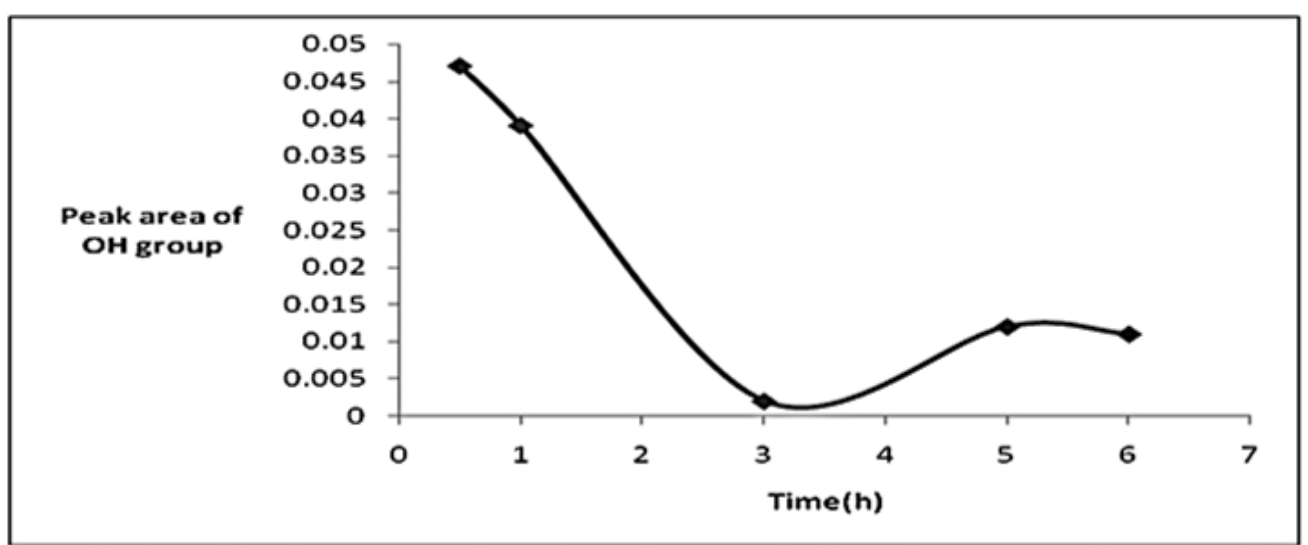

Fig.(7): The relationship between nitration time and absorbance peak area of OH group of product.

From Fig.(6) and (7), it was found that the optimum time of reaction was 3 hours according to the yield percentage and absorbance peak area of $\mathrm{OH}$ group.

Study the effect of nitration products as cetane improvers

The results of sample tests in terms of cetane number utilizing the nitrated products of castor oil esters are shown in Table (3).

Table (3)

Cetane number of samples.

\begin{tabular}{|c||c||c|}
\hline Sample number & Composition of sample & Cetane number \\
\hline \hline 1 & Diesel fuel & 55.7 \\
\hline 2 & $\begin{array}{c}0.1 \% \text { nitrated products of castor } \\
\text { oil esters }+99.9 \% \text { diesel fuel }\end{array}$ & 69.9 \\
\hline \hline 3 & $\begin{array}{c}0.5 \% \text { nitrated products of castor } \\
\text { oil esters }+99.5 \% \text { diesel fuel }\end{array}$ & 71 \\
\hline
\end{tabular}

From Table (3), it may be observed that the increasing in cetane number is achieved through the addition of nitrated products at various concentration and these results agreed with that of Rabello et al. by using additives which prepared from nitration reaction of methyl ester of castor oil [9].

\section{References}

[1] Bubalik M., Beck A., Hancsok J., "Development of Deposit Control Additives for Diesel Fuel", Petroleum \& Coal, 51(3), 158-166, 2009.

[2] Marriott M., "Diesel Quality and EmissionsEuropean Experiences", Reformulated Diesel Symposium, Toronto, Canada, 1994.
[3] Nandi M., Jacobs D., Liotta F., “The Performance of a Peroxide Based Cetane Improvement Additive in Different Diesels Fuels"; SAE Trans. Paper 94201 9, 16541666, 1994.

[4] Hancsok J., Kovacs F., Krar M., "Production of Vegetable Oil Fatty Acid Methyl Esters from Used Frying Oil by Combined Acidic- Alkali Transesterification", Petroleum \& Coal, 46(3), 36-44, 2004.

[5] Quesada J., "Production of Alkenyl Succinic Anhydrides from Low-erucic and Low-linolenic Rapeseed Oil Methyl Esters", Journal of Lipid Science and Technology, 105, 281-287, 2003. 
[6] Mathiyazhagan M., Ganapathi A., Jaganath B., Renganayaki N., and Sasireka N., "Production of Biodiesel from Non-Edible Plant Oils Having High FFA Content", International Journal of Chemical and Environmental Engineering, 2(2), 119-122, 2011.

[7] Suppes G. and Dasari M., "Synthesis and Evluation of Alkyl Nitrates from Triglycerides as Cetane Improvers", Industrial \& Engineering Chemistry Research, 42(21), 5042-5053, 2003.

[8] Garcia M., "Obtaining and Characterization of Helianthus Biodiesel from Castor Oil (Ricinus communis annuus) and Sunflower Grown in Tabasco", International Journal of Applied Science and Technology, 2(9), 58-74, 2012.

[9] Rabello C., Siqueira B., Demenezes R., "Method for Production of Cetane -Index Improvement Additive for Diesel Oil", Patent: 20090100749, 2009.

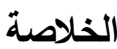

محسّنات السيتان هي مضافُات تعمل على تحسين العددَ

السيتاني لوقود الديزلِ. تتجه الأنظار ألان إلى استخدام

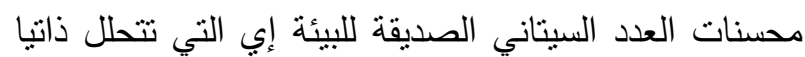
وتعمل على تقليل انبعاث اكاسيد النتروجين والكاربون. تم في البحث الحالي تحضير مركبات النترتة بتفاعل

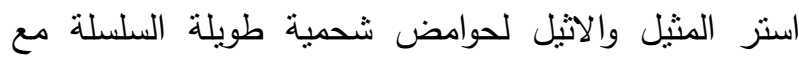
حامض النتريك بوجود انهيدريد الخليك من خلال عملية النترتة، في حين إن استر الاثيل والمثيل تم تحضيره من زيت الخروع من خلال عملية الاسترة.

تم دراسة الظروف المتلى لتفاعل النترتة والتي تشمل


بالاعتماد على النسبة المئوية للمنتوج والنقصان في مساحة قمة امتصاص مجموعة الهيدروكسيل واستخدام الناتج النهائي في تحسين معامل السيتان لوقود الديزل.

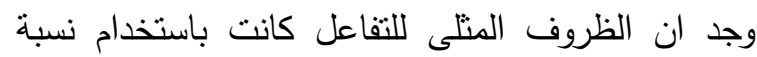
مولية 10 من حامض النتريك ودرجة حرارة 20-10م ولثلاث

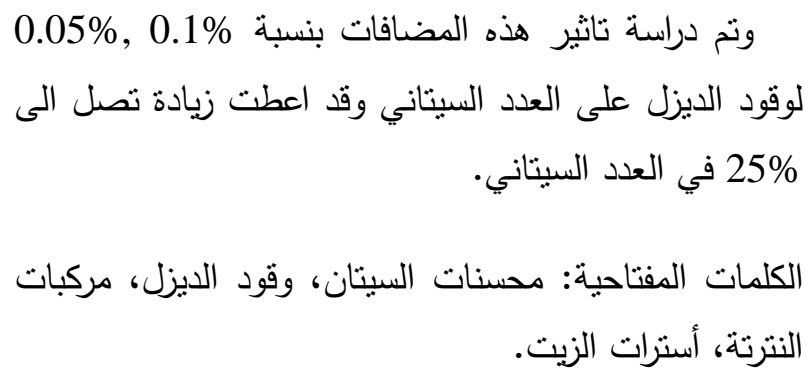

